\title{
Profesorka Bożena Tokarz jubilující
}

\section{Libor Pavera (Praha)}

Nejen v Polsku, ale i ve Slovinsku a v České republice se v průběhu posledních desetiletí stala známou a citovanou literární teoretičkou, historičkou a komparatistkou Bożena Pikola-Tokarz, řádná profesorka teorie literatury a literární historie působící na Slezské univerzitě v Katovicích (Uniwersytet Śląski w Katowicach). V posledních měsících oslavila významné životní jubileum (narozena 17. 10. 1946), k němuž se pojí i samostatný svazek Studií o překladu (sv. 42, Katowice 2016). ${ }^{1}$ Zatímco místem jejího zaměstnání je téměř po celou badatelskou dráhu katovická univerzita, její badatelská práce se soustředuje na dva hlavní problémové okruhy: jedním je teorie literatury v nejširším slova smyslu, úžeji pak teorie překladu, spjatá v českém prostředí zejména s Jiřím Levým a pracemi, které zde předčasně zemřelý badatel zanechal a které dosud tvoří živý a nepřehlédnutelný zdroj poznání i inspirací pro budoucí bádání, druhý tvoří dějiny slovanských literatur 20. a 21. století, z nichž zřetelně převládá badatelčin zájem o literaturu slovinskou a polskou, řidčeji o ukrajinskou nebo českou a slovenskou. V uvedených oblastech výzkumu vyškolila rovněž několik doktorandů, kteří působí na polských i zahraničních slavistikách a polonistikách.

Absolvovala vysokoškolská studia polonistická a romanistická. Polonistická zakončila v roce 1969 na univerzitě v Lodži. Tam, jak známo, působila mezinárodně známá a po světové literární vědě a filozofii široce rozhleděná badatelka profesorka Stefania Skwarczyńska. Od meziválečné doby byla spjata s výzkumem žánrů a kategorií žánrovosti: právě Skwarczyńská během 2. světové války a po jejím skončení dala impuls ke vzniku speciálního vědeckého časopisu, který měl přinášet informace o dění v oblasti genologie a hesla o jednotlivých žánrech; z hesel měl později vzniknout slovník žánrů (podařilo se ho vydat až několik let po smrti S. Skwarczyńské jednomu z jejích žáků - Stownik rodzajów i gatunków literackich, již dvě vydání).

U prof. Stefanie Skwarczyńské absolvovala magisterskou prací nazvanou Twórczość Harasymowicza s podtitulem Próba monografii v roce 1969. O tři roky později pak byla S. Skwarczyńská promotorkou doktorské práce Bożeny Tokarzové s titulem Topos arkadyjski we wspótczesnej poezji polskiej (jego kontynuacje i degradacje). Z obou kvalifikačních prací, které tu byly uvedeny, publikovala některé fragmenty v časopisech a sbornících; jejich podrobnější bibliografie se najde v citovaném sborníku. První její knižní prací, kterou napsala ve spolupráci s prof. Stefanem Zabierowskim, je Teoria literatury: Metodologia

1 Jde o sérii vycházející po několik let pod redakcí rusisty Piotra Fasta: Komunikacja międzykulturowa (Przektad / komparatystyka / teoria i historia literatury) : Ksiega jubileuszowa dedykowana Profesor Bożenie Tokarzowej. Red. Monika Gawlak - Alina Świeściak. Katowice: Śląsk, 2016. 599 s. Kniha obsahuje rovněž bibliografii monografií a studií badatelky. 
badań literackich (1980). Někteří její posluchači ještě po létech vzpomínají na inspirativní přednášky a semináře $\mathrm{s}$ badatelkou, která byla výborně obeznámena se světovou literární vědou, měla schopnost nadhledu, prokazovala schopnost kontextově dávat jevy do souvislostí a projevovala se uměním syntézy. V neposlední řadě je nutno připomenout, že dostala do vínku dar předávat svá zjištění a zkušenosti mladším kolegům, studentům a doktorandům. Je přísnou a z kvality nic neslevující, ale přesto oblíbenou a vyhledávanou vysokoškolskou přednášející.

Od prosince roku 1971 je spjata s katovickou univerzitou. Nejprve s její polonistikou, od roku 1989 pak s institutem slovanských jazyků a literatur (sídlí již několik let v blízkém Sosnowci). Na univerzitě v Katovicích v průběhu svého působení plnila rovněž některé akademické a řídící funkce (proděkanka, vedoucí katedry apod.). V letech 1984 až 1988 působila jako lektorka polského jazyka v Institute d'Etudes Slaves na Université de Clermont Ferrand II. Tam rovněž zahájila svá romanistická studia.

V roce 1983 vyšla její první samostatná monografie Mit literacki. Od mitu rzeczywistości do zmiany substancji poetyckiej. I když východiskem práce Bożeny Tokarzové bývají zpravidla literární texty, problematiku vždy ku prospěchu bádání posouvá ještě směrem do oblasti kulturních a filozofických kontextů. Ještě výrazněji nežli v prvé knize je to zřejmé z knihy Poetyka Nowej Fali, vydané v roce 1990. Soustředila se v ní na tvorbu z tehdejšího pohledu současnou, na polskou poezii, v jejímž kontextu kolem roku 1968 dochází k výrazné změně poetiky. Vybrala si ke studiu autory a texty, kteří tvoří jistou ucelenou formaci (S. Barańczak, J. Kornhauser, R. Krynicki, T. Różewicz, J. Tuwin, A. Zagajewski aj.), navíc jde o autory, kteří nejednou jsou tvůrčími osobnostmi nejen ve smyslu poetickém, ale i ve smyslu vědeckém ( $\mathrm{S}$. Barańczak a jeho studie o překladu, J. Kornhauser zároveň literární historik a kritik apod.). Na základě uvedené práce se v roce 1991 stala habilitovanou doktorkou.

V jejích metodách práce probleskují ty, s nimiž se setkávala v průběhu svých vysokoškolských studií - zejména při vědecké výchově u prof. S. Skwarczyńské, u jiných slavistů (napřr. prof. Marie Bobrownické) nebo které se vynořily při její badatelské práci v posledních letech (zejména kognitivní pojetí, které našlo uplatnění nejen v poetologii, ale rovněž má své místo v teorii i praxi překladu). Sem, do oblasti teorie a praxe polských překladů slovinské literatury a slovinských překladů polské literatury náleží situovat její studie o polských překladech milostné poezii Prešernovy, jednoho z největších slovinských básníků 19. století, o podobě poezie T. Różewicze a Cz. Miłosze ve slovinských překladech (zejména v knize Wzorzec, podobieństwo, przypominanie, Katowice 1998). S novými metodami literární vědy se jistě Bożena Tokarzová seznamovala rovněž za svého francouzského pobytu v Université de Clermont Ferrand II. - ve světě tehdy svobodném na př́istup k informacím.

Od roku 1981 je ve stálém kontaktu se slovinským prostředím filologů a spisovatelů, nesporně rovněž zásluhou svého manžela, profesora obecné jazykovědy Emila Tokarze, mj. slovinisty a paleoslavisty. Ke slovinskému prostředí a slovinské literatuře se váže rovněž nejedna její odborná studie, ba kniha - Med destrukcijo in konstrukcijo. O poeziji Srečka Kosovela v kontekstu konstruktivizma (Między destrukcja a konstrukcja. O poezji Srečka Kosovela w kontekście konstruktywistycznym, polsky 2004, slovinsky 2013 v překladu Primože 
Čučnika). Ukazuje v ní, jak Kosovelovu poezii vnímala skupina polských konstruktivistů, tzv. krakovská avantgarda.

Bożena Tokarzová je také členkou redakcí slovinských odborných časopisů Jezik in slovstvo (od roku 2001), Ars et Humanitas (od roku 2006) a Slavia Centralis (od roku 2009). 18. 6. 2015 byla pak zvolena za členku-korespondentku Slovinské akademie věd (SAZU).

V roce 2004 byla Bożena Tokarzová jmenována prezidentem Polské republiky řádnou profesorkou humanitních věd. O několik let později pomýšlí na cyklus prací týkajících se výzkumu překladu: svůj sen si plní sérií publikací Przektady Literatur Stowiańskich, kterou později proměnila v odborný recenzovaný časopis (srov. www.pls.us.edu.pl). Sama pak vydala počet ze svého badatelského usilování v oblasti překladatelství - s využitím četných příkladů z polské, francouzské i slovinské literatury - v knihách Wczorzec, podobieństwo, przypominanie (Ze studiów nad przektadem artystycznym) (1998) a Spotkania : Czasoprzestrzeń przektadu artystycznego (2010).

Přejeme badatelce u příležitosti jejího životního jubilea, aby se její zdravotní stav vyvíjel správným směrem, protože od dobrého fyzického stavu a dobrého pocitového světa závisí stav duše a zdárná realizace projektů, o které v případě prof. Bożeny Tokarzové nikdy není nouze. Jde o projekty náročné, kvalitní a kvalifikované. Sluší se závěrem ještě připomenout, že jak prof. Bożena Tokarzová, tak její manžel, prof. Emil Tokarz, mj. zakladatelé Towarzystwa polsko-słoweńskiego, byli v roce 2007 oceněni mezinárodní Cenou T. Pretnara za šíření slovinské kultury a literatury ve světě a stali se tak „ambasadory slovinské kultury“.

prof. PhDr. Libor Pavera, CSc.

Konšelská 426/25

18000 Praha 8, Česká republika

I.pavera@seznam.cz 
